\title{
Development of Green Biorefinery for Biomass Utilization: A Review
}

\author{
Shuangning Xiu* and Abolghasem Shahbazi \\ Department of Natural Resources and Environmental Design, North Carolina A\&T State University, \\ Greensboro, North Carolina, 27411 USA
}

Received January 18, 2015; Accepted February 25, 2015; Published February 28, 2015

\begin{abstract}
Green biorefineries are multiproduct systems, which utilize green biomass as an abundant and versatile raw material for the manufacture of industrial products. It represents an innovative approach to alternative applications of surplus grassland biomass. An overview of the main aspects, activities, and processing technologies was presented in this paper. Recent developments on the green biorefinery in both Europe and North America were discussed. A focus for future R\&D work in this field was recommended.
\end{abstract}

Keywords: Green Biorefinery; Biomass; Grass; Biofuel; Renewable Energy

\section{Introduction}

Non-renewable fossil fuels, coal, oil and natural gas are being consumed worldwide at a very fast pace (Shafiee and Topal 2009). The United States consumes more than $25 \%$ of international oil production, but possesses just $1.6 \%$ of its oil reserves (US EPA 2009). If not replaced by alternative energy sources, fossil fuels will eventually be depleted while $\mathrm{CO}_{2}$ in the atmosphere will rise to levels with dangerous consequences. Fossil fuels are the major source of environmental pollutants, greenhouse gases, and ocean acidification. Sustainable development requires the use of renewable resources as alternative feedstocks for chemical, fuel and material production.

Biomass represents an attractive source for the production of fuels and chemicals due to its versatility, renewable nature, and low environmental impacts. Considerable attention has been given to lignocellulosic biomass such as agricultural residues and energy crops for biofuel production. US Department of Energy (DOE) and Department of Agriculture (USDA) projected that the US biomass resources could provide approximately 1.3 billion dry tonnes of feedstock for biofuels, which would meet about $40 \%$ of the annual US fuel demand for transportation (Perlack et al. 2005). The overall goal is to replace $20 \%$ of the United States transportation fuel imports (35 billion barrels per year) by 2017 (Biomass Research and Development Board 2008). Obviously, a significant need exists for exploring its efficient utilization.

There has been an increasing interest in the use of perennial grasses as energy crops in the US and Europe since the mid-1980s. Over time, various conversion technologies have been used to produce biofuels from perennial grasses. Conversion technologies can be subdivided into two categories: thermochemical treatment (e.g., pyrolysis, gasification, hydrothermal liquefaction, and combustion) and biological treatment (e.g., fermentation, anaerobic digestion). Water contained in green biomass 
poses the negative effect on the thermochemical treatment, as it requires the high heat of vaporization. In general, drying the "nature-wet" raw material is needed for the thermochemical conversion technologies, which limits the options for green biomass as feedstock and overall process economy.

Researchers also found that biomass from semi-natural grasslands is difficult to exploit in conventional bioenergy-converting systems, as the chemical composition is detrimental for both conventional anaerobic digestion as a result of high fiber concentrations (Prochnow et al. 2005, Richter et al. 2009) and for cellulosic bioethanol fermentation due to its resistance to enzymatic attack. Cellulosic biomass must be pretreated before it can be enzymatically hydrolyzed.

Despite advances in technology, the ability to produce biofuel as a single source of revenue remains infeasible (US EPA 2007) and exhibits a need for further cost reductions. One possibility for ameliorating this problem is to adopt a biorefinery approach which diversifies the output streams of a biofuel facility by generating diverse co-products alongside biofuel for increased revenue generation (Takara and Khanal 2011).

Analogous to the petroleum refinery that processes a barrel of crude oil into many petroleum based products including gasoline, diesel fuels and petroleum based chemicals, the biorefinery converts biomass into multiple biofuels and bioproducts. The ability to process raw materials into a varied product stream greatly enhances the versatility of the biorefinery to meet the economic demands of the free market and compete globally. This pioneering concept has been examined for several feedstocks, including alfalfa and Bermuda grass for biofuel and protein recovery applications (Buentello et al. 1997, Dale and Matsuoka 1981, Dale 1983).

The technological concept of green biorefinery represents an innovative approach to alternative applications of green biomass. This article comprehensively reviewed the state of the art, the feedstocks, and the processing technologies that are used to produce multiproduct in the green biorefinery. Besides, the research development status in both Europe and North America were discussed. It also recommended future R\&D work in the green biorefinery field.

\section{Green Biorefinery}

\section{Concept of Green Biorefinery}

Green biorefineries are multiproduct systems, which utilize green biomass as an abundant and versatile raw material for the manufacture of industrial products. The concept is currently in an advanced stage of development in several European countries, especially Germany, Denmark, Switzerland, the Netherlands and Austria (Xiu and Shahbazi 2013).

The basic idea of this concept is to utilize the whole green biomass (like grass, alfalfa, and various other sources) to generate a variety of products that are either valuable products themselves or form the basis for further production lines. Besides biobased materials, fuels and energy may be supplied by this technology. The feasibility of a biorefinery based on grass has been successfully demonstrated by (Grass and Hansen 1999).

In green biorefinery, the careful wet or green fractionation technology is used as the first step (primary refinery) to isolate the green biomass substances in their natural form. Thus, green biomass are separated into a fiber-rich press cake and a nutrient-rich 
press juice (Figure1). Both fractions have an economic value. Figure1 illustrates the array of potential products from a green biorefinery that can be generated by the downstream processing of press juice and press cake.

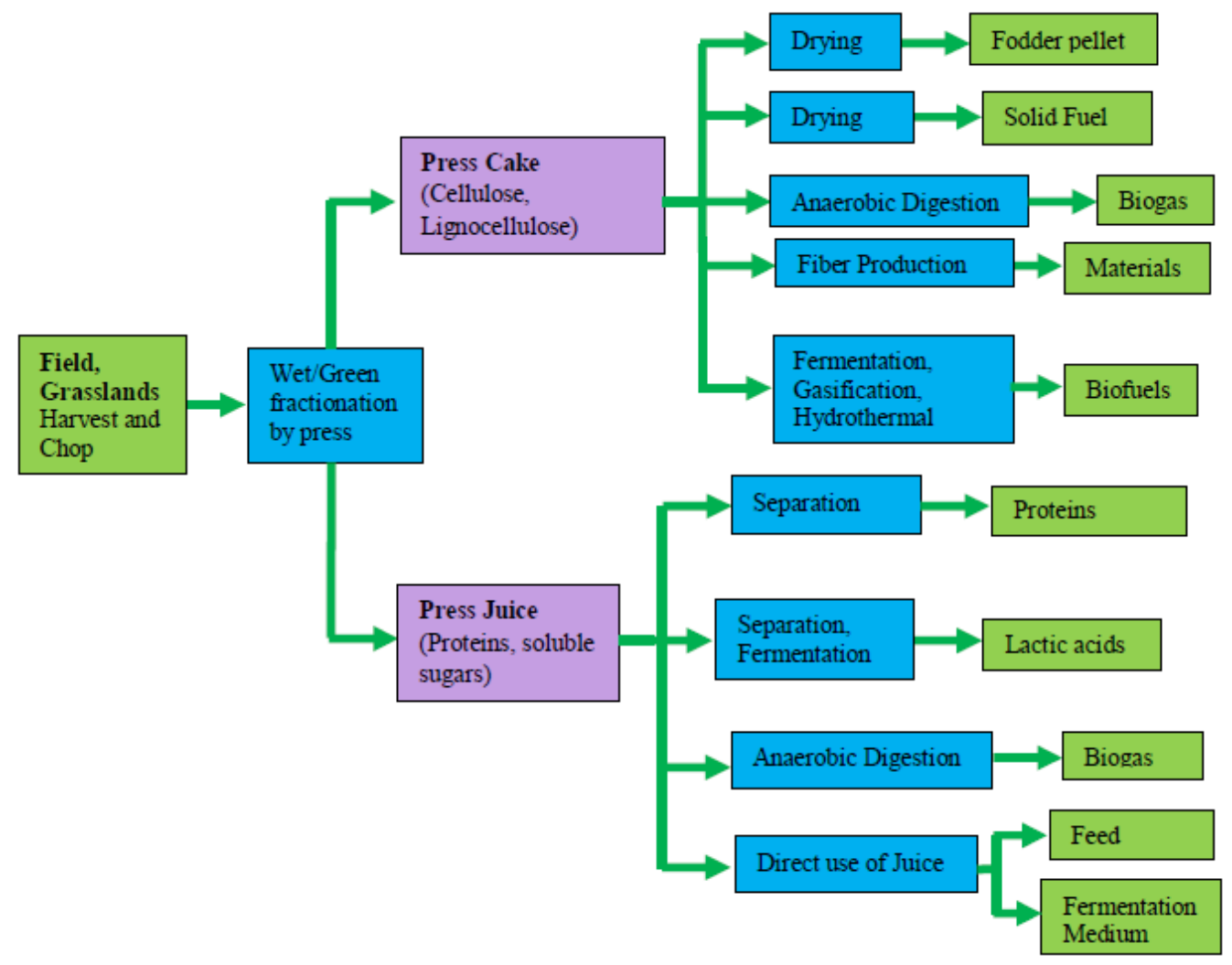

Figure 1. A green biorefinery system for green biomass utilization.

\section{Feedstocks for Green Biorefinery}

Currently, the feedstocks used for green biorefinery are mainly green grasses, for example, grass from cultivation of permanent grass lands, closure fields, nature preserves, or green crops such as Lucerne (or Alfalfa), clover, and immature cereals from extensive land cultivation (Kamm and Kamm 2007). The interesting valuable components of fresh biomass are proteins, soluble sugars, and the fiber fractions (i.e. cellulose, hemicelluloses, and lignin parts).

Table 1 shows the chemical composition of representative types of green biomass. In general, biomass are typically composed of $75-90 \%$ of sugar polymers, with the other $10-25 \%$ of biomass principally being lignin (Huber and Dumesic 2006). For herbaceous grass plants, typical contents in the dry mater are in the range of 6-15\% for protein, 20 $55 \%$ water soluble extracts containing 5-16\% soluble sugars and the raw fiber parts (cellulose 20-30\%, hemicelluloses 15-25\%, and lignin 3-10\%) (Mandl 2010).

In the past, most of attention has focused on the cellulose, hemicelluloses, and lignin existing in cellulosic materials. However, there are also considerable amounts of protein available in these biological materials as indicated in Table 1. For the biomass species listed, aquatic organisms, especially algal species, often have higher protein content than other biomass resources. For example, Spirulina algae have a high protein content of around $60 \%$. Since a kilogram of protein is generally much more valuable than 
an equal weight of carbohydrate, aquatic organisms can be used as a good candidate for green biorefinery in respect of high value protein recovery.

Nowadays, algae are viewed as next generation biofuel feedstocks because of their superior photosynthetic efficiencies and higher carbon capturing capabilities compared with terrestrial plants (Hasan et al. 2013). Algae are usually composed of lipids, proteins, nucleic acids, and no-cellulosic carbohydrates. Conversional algae-to-biodiesel technology requires drying of the algal biomass followed by solvent and or/mechanical extraction. The energy consumed in drying process is more than $75 \%$ of the total energy consumption (Lardon et al. 2009). In the green refinery, the wet fractionation of algae can be employed to reduce the need for energy-intensive drying operations and to utilize nutrient-rich green juice for value-added co-product developments (e.g., protein) that would otherwise be destroyed in downstream processing.

Besides algae, energy crops such as switchgrass and grant miscanthus can be good candidates for green biorefinery due to the high yields of biomass per hectare and year, low fertilization and pesticide requirements, broad adaptability, and greater ability to sequester carbon in the oil than most other grasses. Switchgrass (Panicum virgatum L.) is a perennial native grass adapted to the prairies of North America, and was identified by the DOE as a primary species for development as an energy crop. It has the ability to grow well on marginal croplands without heavy fertilization or intensive managements and has a potential for the high fuel yield (Woodward 2008).

Table 1. Composition of representative biomass resources

\begin{tabular}{|c|c|c|c|c|c|c|}
\hline Biomass type & \multicolumn{2}{|c|}{ Aquatic organisms } & \multicolumn{2}{|c|}{ Herbaceous } & \multicolumn{2}{|c|}{ Woody } \\
\hline Name & Spirulina & Duckweed & $\begin{array}{l}\text { Bermuda } \\
\text { grass }\end{array}$ & $\begin{array}{l}\text { Switch } \\
\text { grass }\end{array}$ & Poplar & Pine \\
\hline \multicolumn{7}{|c|}{ Component (dry wt $\%$ ) } \\
\hline Celluloses & $<1$ & 11.9 & 31.7 & 37 & 41.3 & 40.4 \\
\hline Hemicellulose & 1 & 13.8 & 40.2 & 29 & 32.9 & 24.9 \\
\hline Lignin & $<1$ & 3.2 & 4.1 & 19 & 25.5 & 34.5 \\
\hline Crude protein & 64 & 35.1 & 12.3 & 3 & 1.7 & 0.7 \\
\hline Crude lipid & 5 & 5 & 11.9 & -- & -- & -- \\
\hline Ash & 11 & 16.5 & 5 & 6 & 0.8 & 0.5 \\
\hline Total & 100 & 92.4 & 93.3 & 94 & 102.9 & 101.0 \\
\hline Reference & $\begin{array}{l}\text { (Vardon et } \\
\text { al. 2012) }\end{array}$ & $\begin{array}{l}\text { (Xiu et al. } \\
\text { 2010) }\end{array}$ & $\begin{array}{l}\text { (Huber and } \\
\text { Dumesic } \\
\text { 2006) }\end{array}$ & $\begin{array}{l}\text { (US } \\
\text { Department } \\
\text { of Energy) }\end{array}$ & $\begin{array}{l}\text { (Huber and } \\
\text { Dumesic } \\
\text { 2006) }\end{array}$ & $\begin{array}{l}\text { (Huber and } \\
\text { Dumesic } \\
\text { 2006) }\end{array}$ \\
\hline
\end{tabular}

Grant Miscanthus (Miscanthus $x$ giganteus) is a tall perennial grass that reproduces by underground rhizomes and has been evaluated in Europe during the past 10 years as a bioenergy crop. It is characterized as having broad adaptability, high water and fertilizer use efficiency, excellent pest resistance, and tremendous biomass production. Tonnages of between 6-20 tonnes/acre are anticipated from miscanthus. Miscanthus stems may be used as fuel for the production of heat and electric power or as a feedstock for the production of cellulosic ethanol. In general, the advantages of using energy crop as feedstock is its high biomass profit per hectare and a good coupling with national and state's priority to use energy crops as second generation biofuel feedstock. 


\section{Current Processing Technologies for Green Biorefinery}

\section{Primary Separation}

The initial fractionation of the green biomass remains an essential operation for green biorefinery process. Green crop fractionation is now studied in about 80 countries (Singh 1996). Water contents in tropical grasses can be as high as $80-85 \%$ or similarly $\sim 90 \%$ for aquatic species. Those "nature-wet" raw materials require a fast primary processing or the use of preservation methods, like silage or drying. But due to the energy consumption of thermal dryers, the biomass is seldom transformed after drying, so that mechanical fractionation of the wet material is usually the first unit operation in the green biorefinery plant. Screw press machine has been primarily used to press the green juice out of the green biomass. For vegetative biomass like alfalfa, clover and grass, screw presses remove approximately $55-60 \%$ of the inherent liquid (Kamm et al. 2009). Nevertheless other means of preprocessing have also been applied, such as thermal mechanical dewatering method, simultaneous application of a pulsed electric field, and superimposition of ultrasounds (Arlabosse et al. 2011). Wachendorf et al. investigated the hydrothermal conditioning at different temperatures $\left(5,60\right.$ and $\left.80^{\circ} \mathrm{C}\right)$ and mechanical dehydration on mass flows of plant compounds into the press fluid for five grassland pastures typical of mountain areas of Germany. The underlying objectives were to obtain a juice in larger quantity and of better quality (Wachendorf et al. 2009).

\section{Processing of Press Juice to Value-added Products}

The green juice contains proteins, free amino acids, organic acids, dyes, enzymes, hormones, other organic substances, and minerals (Kamm and Kamm 2007). The green juice is a good source for high quality fodder proteins, cosmetic proteins, human nutrition or platform chemicals like lactic acid and lysine or can be used as substrate for bio-gas production (Kamm et al. 2009). The main focus is to process the juice into products such as lactic acid and corresponding derivatives, amino acids, ethanol, and proteins.

The best known products which can be obtained from grassland biomass are proteins. Proteins are essential elements of the nutrition for humans and animals, and important raw materials for adhesives and for the pharmaceutical and cosmetics industries. Protein extraction from fresh alfalfa have been explored since 80s' (Dale and Matsuoka 1981, Dale 1983, Pirie 1986).

High-quality fodder proteins and proteins for cosmetic industry may be produced through the fractionation of the green juice proteins in different separation and drying processes. The fodder proteins could be a complete substitute for soy proteins. They even have a nutritionally physiologic advantage due to their special amino acid patterns. The general approach to leaf protein production is to harvest fresh plant materials, grind the plant tissue, squeeze out a protein rich juice and then heat the juice to precipitate and recover the protein (Pirie 1971).

Recently, L-lactic acid received increased attention as a feedstock monomer for a biodegradable polymer-polylactide (PLA). A recent study has demonstrated that, after separation of proteins from alfalfa press juice, the supernatant can be used as fermentation media for the production of the ammonium lactate, L-lysine-L-Lactate, which acts as intermediates for the production of lactic acid sequence products like lactide (Leiß et al. 2010). Another study evaluated the possibility of recovery of lactic acid from various grass silages through a two-step process, in which the crude liquid press extract was pre-treated with ultrafiltration membranes followed by purification with 
mono-polar electrodialysis (Danner et al. 2000). Lactic acid can also be separated from grass silage juice by chromatography using neutral polymeric resin (Thang and Novalin 2008).

Alternatively, press juice can be directly used as fermentation media for organic acids production. When the fermentation experiments of lactic acid bacteria were carried out in brown juice, the result showed that juices from grass, clover and alfalfa can easily be converted to a stable universal fermentation media by adding more carbohydrates or for production of other organic acids or amino acids in the second stage fermentation (Anderson and Kiel 2000). This is a new way of simultaneous preservation and utilization of plant juice for fermentation purposes.

\section{Processing of Press Cake to Value-added Products}

The press cake can be used as solid fuels, for the production of green feed pellets/fodder pellets, as a raw material for the production of chemicals, such as levulinic acid, and for the conversion to syngas and hydrocarbons (synthetic biofuels).

Richter et al. evaluated the properties of the press cakes as solid fuel, which was derived from five species-rich, semi-natural grasslands via thermal mechanical dewatering method (Richter et al. 2009). Their results showed that compared with the grassland silages used as parent materials, the press cakes generated significantly lower concentrations of elements detrimental for combustion. The ash softening temperature of the press cakes increased significantly, which was comparable to beech wood. Overall, the solid fuel from press cakes was of superior quality compared with conventional hay. However, the increase in the higher heating value of these press cakes was not statistically significant.

Other uses of the press cakes include manufacturing fodder pellets and biogas production. The residues of green biorefinery are suitable for the production of biogas, combined with the generation of heat and electricity. In Europe, the green crop drying industry produces fodder pellets by drying crops such as perennial ryegrass, Italian ryegrass, clover grass and alfalfa (Thomsen 2005, Walker et al. 1982). From an energetic point of view, it is far better to use the press cake as a silage feed and/or bioenergy.

Since the press cake is rich in fiber, researchers have commented on the potential use of press cake for fiber applications (e.g., insulation materials, fiber boards, horticultural substrates, and pulp \& paper) (Mandl 2010). However, little or no attention has been devoted to removing and upgrading the carbohydrate fraction of press cake for fiber applications. Therefore, there is a need to develop and demonstrate technologies for utilizing green biomass for various fiber applications.

Biomass conversion to fuels and chemicals is receiving a great deal of attention. The need for a billion tonnes of biomass to produce enough biofuel to replace $30 \%$ of US petroleum consumption has been reported by the US DOE (Woodward 2008). The integrated green biorefinery system will certainly enhance the economics of biofuel production by generating value-added co-products from biomass. The research contributed to this effort has been primarily focused on protein recovery in bioethanol production (Dale 1983, Kammes et al. 2011, Takara and Khanal 2011).

Besides fuel ethanol production, other biofuels and chemicals can be produced from press cake as well. The thermochemical conversion process is another promising method of converting the press cake for energy purposes. For instance, the syngas produced from grassed may be converted to fuel alcohols via the Fischer-Tropsch process (Boateng et al. 2006). 


\section{Research Development Status in Green Biorefinery}

\section{Research Status in Europe}

The most notable successes in research and development in the field of green biorefinery system research happened in several European countries. The pilot scale processing trials in Austria (Utzenaich), Denmark (Esbjerg), Switzerland (Obre), and Germany (Brandenburg) have produced lactic acid, amino acids, leaf juice protein concentrate, fiber products, and biogas by setting up integrated refineries (Mandl 2010). In 2001, the first Green Biorefinery started operation in Switzerland with a design load of 5000 tonnes dry matter of grass per year and a combined output of fibers $(0.4$ tonnes per ton input), protein $(160 \mathrm{t} / \mathrm{t})$, and bioenergy $(500 \mathrm{kWh} / \mathrm{t})$ (Baier and Grass 2001). A green biorefinery demonstration plant in Havelland (Germany) is under construction, which will have an annual capacity of 20,000 tonnes alfalfa and grass biomass and can be diversified in modules for the production of platform chemicals and synthesis gas. The demonstration facility will directly link to the existing green crop drying plants (Kamm et al. 2010).

Since 1999, Dr. Kromus's research group in Australia has started to develop the Austrian green biorefinery and the results lead to the installation of a basic pilot plant in 2004 (Kromus et al. 2004). A key element in their concept is the utilization of fermented grass (i.e. grass silage) instead of fresh biomass.

However, the majority of the biorefineries in Europe are based on wet fractionation process to isolate the substrate fractions in their natural form (i.e. pressed fiber and nutrient-rich juice from fresh grass or silage) and to develop platform chemicals from the green/brown juice. The press cake has been primarily used for production of fodder pellet and biogas. Little or no attention has yet been focused on the utilization of the press fiber for fuel purpose, especially as raw materials for biofuel production.

\section{Research Status in North America}

The research development in green biorefinery in North American is not as significant as that in Europe. The research has being primarily focused on protein recovery in ethanol production. Various groups in North American have been examining various grasses for their potential as feedstocks for biofuel production. Haque et al. in Oklahoma evaluated productivity of four grasses (Bermuda, faccid, love and switch) and reported that switchgrass is the most viable species for biofuel production (Haque et al. 2009). Woodward evaluated the potential for alfalfa, switchgrass, and miscanthus as biofuel corps in Washington State (Woodward 2008). Research group in Nebraska also found that switchgrass-derived ethanol produced $540 \%$ more energy than was required to manufacture the fuel. One acre of grassland could, on average, delivers 320 gallons of bioethanol (Schmer et al. 2008). Another research group in Hawaii has developed an innovative biorefinery approach to green processing of tropical banagrass into biofuel and biobased products (Bals et al. 2007). Edwards et al. has extracted leaf protein form orchard grass and switchgrass, which is indented to use as a source of protein for livestock (Edwards et al. 1975).

\section{Future R\&D Work}

Table 2 summarized various green biorefinery developments through the world. The most promising products which have been identified from the green juice are 1) proteins: as feed or food (low price), hydrolyzed as amino acids for cosmetics or 
pharmaceutical industry, and 2) lactic acid: for neutralization/buffering, as solvent (ethyl lactate), or bioplastics (PLA=polylactide).

Table 2. Green biorefinery of different green biomass in literature

\begin{tabular}{|l|l|l|l|l|}
\hline \multirow{2}{*}{ Grass Type } & \multicolumn{2}{|c|}{ Main products } & Country & Reference \\
\cline { 2 - 5 } $\begin{array}{l}\text { Alfalfa, mixed } \\
\text { grass }\end{array}$ & $\begin{array}{l}\text { Press Juice } \\
\text { media }\end{array}$ & Press Cake & Germany & $\begin{array}{l}\text { (Kamm } \text { et al. } \\
\text { 2010, Richter } \text { et al. } \\
\text { 2009) }\end{array}$ \\
\hline $\begin{array}{l}\text { Grass silage } \\
\text { (red clover and } \\
\text { ryegrass }\end{array}$ & Protein Lactic acid & Fibers & Animal feed, \\
\hline Alfalfa & Protein & Ethanol & $\begin{array}{l}\text { (Danner } \text { et al. } \\
2000)\end{array}$ \\
\hline Tropical banagrass & $\begin{array}{l}\text { Edible fungus for } \\
\text { aquaculture feed } \\
\text { supplement }\end{array}$ & Ethanol & US & $\begin{array}{l}\text { (Takara and } \\
\text { Khanal 2011) }\end{array}$ \\
\hline $\begin{array}{l}\text { Orchard grass and } \\
\text { switchgrass }\end{array}$ & Protein as animal feed & Ethanol & US & $\begin{array}{l}\text { (Kammes } \text { et al. } \\
\text { 2011) }\end{array}$ \\
\hline $\begin{array}{l}\text { Grass, clover and } \\
\text { alfalfa }\end{array}$ & Fermentation media & $\begin{array}{l}\text { Fodder pellets for } \\
\text { animal feed }\end{array}$ & Denmark & $\begin{array}{l}\text { (Anderson and } \\
\text { Kiel 2000) }\end{array}$ \\
\hline Silage & Protein as animal feed & Fiber, biogas & Switzerland & $\begin{array}{l}\text { (Baier and Grass } \\
\text { 2001) }\end{array}$ \\
\hline Switch grass & Protein & n/a & US & (Bals et al. 2007) \\
\hline
\end{tabular}

To date, the economic viability of green biomass fractionation press, for instance the ProXan-Process (Edwards et al. 1975) used to produce a marketed leaf protein concentrate, depends, to a large extent, on the utilization of the solid fraction as high quality ruminant feed (Sinclair 2009). The production of only one product such as, for example, a protein product would not create sufficient revenue to cover the cost of the raw material and the related processing costs.

In the area of the press cake utilization, the research interest is directed to fodder pellets and biogas production in Europe and ethanol production in US, respectively. The alternative use of grass press cake as a potential raw material for second-generation biofuels has not been worked on in detail so far, but it is indeed worthwhile exploring. Co-generation of biofuels from the green biorefinery would certainly "upgrade" the green biorefinery approach in the minds of strategists and decision-makers. Besides biofuels, the press cake could also be feedstock for generation of bioproducts, such as lactic acid, which is a base chemical for many applications, from food additive to solvents to plastics. Therefore, there is a need to develop and evaluate the state-of-art biomass conversion technologies for generating biofuels and bioproducts from grass press cake.

\section{CONCLUSIONS}

A green biorefinery offers a solution to generate a variety of products and energy without directly interfering in the food supply chain by utilizing surplus resources. Some R\&D work has been done over the last 15 years and technologies have been pushed forward to demonstration plants in several European countries. However, there is no real impact from an industrial perspective so far. Some problems affecting its industrial utilization and recommendations are described as follows: 
1 Feedstock selection and evaluation. Currently, the feedstocks used for green biorefinery are mainly green grass and/or green crops. Better management of species and varieties including the use of second generation biofuel feedstocks (e.g., microalgae) could reduce the associated carbon footprint and improve the production efficiency of the green biorefinery.

2 The development of technologies for the production of biofuels and bioproducts from the press cake. In the area of the press cake utilization, the research interest is directed to fodder pellets and biogas production in Europe and ethanol production in US, respectively. Little attention has been devoted to the alternative use of press cake as a raw material for second-generation biofuels and bioproducts production. Therefore, there is a growing demand for developing and evaluating the state-of-art biomass conversion technologies for generating biofuels and bioproducts from grass press cake. Thus, the overall economic efficiency of a green biorefinery will improve.

3 Development of industrial green biorefinery technologies. Over the years, different green biorefinery schemes have been proposed and investigated. However, none of them has been commercialized yet. Research should focus on the further development of alternative products and pave the way for the implementation of a green biorefinery.

4 Evaluation of the overall sustainability of process technologies. Research should evaluate these aspects of sustainability considering costs and emissions involved with input production, feedstock production, feedstock harvest, transport, storage, pre-processing, processing, product transportation, and consumption.

\section{ACKNOWLEDGMENTS}

The authors are grateful for the support of the USDA-CSREES-Evans-Allen Project, Grant No. NCX-272-5-13-130-1.

\section{CONFLICTS OF INTEREST}

The authors declare that there is no conflict of interests regarding the publication of this paper.

\section{REFERENCES}

Anderson, M., and Kiel, P. (2000). "Integrated utilization of green biomass in the green biorefinery." Industrial Crops and Products, 11, 129-137. DOI: 10.1016/S09266690(99)00055-2

Arlabosse, P., Blanc, M., Kerfaï, S., and Fernandez, A. (2011). "Production of green juice with an intensive thermo-mechanical fractionation process. Part I: Effects of processing conditions on the dewatering kinetics." Chemical Engineering Journal, 168(2), 586-592. DOI: 10.1016/j.cej.2011.01.027

Baier, U., and Grass, S. (2001). "Bioraffination of Grass, Anaerobic Digestion 2001." Proceedings of the 9th World Congress for Anaerobic Conversion for Sustainability, Antwerpen.

Bals, B., Teachworth, L., Dale, B., and Balan, V. (2007). "Extraction of Proteins from Switchgrass Using Aqueous Ammonia within an Integrated Biorefinery." Applied 
Biochemistry and Biotechnology, 143(2), 187-198. DOI: 10.1007/s12010-0070045-0

Biomass Research and Development Board (2008). "National Biofuels Action Plan." http://wwwl.eere.energy.gov/biomass/pdfs/nbap.pdf. [Accessed on February 20, 2015]

Boateng, A. A., Jung, H. G., and Adler, P. R. (2006). "Pyrolysis of energy crops including alfalfa stems, reed canarygrass, and eastern gamagrass." Fuel, 85(1718), 2450-2457. DOI: 10.1016/j.fuel.2006.04.025

Buentello, J. A., Gatlin, D. M., and Dale, B. E. (1997). "Evaluation of Coastal Bermuda Grass Protein Isolate as a Substitute for Fishmeal in Practical Diets for Channel Catfish Ictalurus punctatus." Journal of the World Aquaculture Society, 28(1), 5261. DOI: 10.1111/j.1749-7345.1997.tb00961.x

Dale, B. E., and Matsuoka, M. (1981). "Protein recovery from leafy crop residues during biomass refining." Biotechnology and Bioengineering, 23(6), 1417-1420. DOI: 10.1002/bit.260230624

Dale, B. E. (1983). "Biomass refining: protein and ethanol from alfalfa." Industrial \& Engineering Chemistry Product Research and Development, 22(3), 466-472. DOI: 10.1021/i300011a016

Danner, H., Madzingaidzo, L., Holzer, M., Mayrhuber, L., and Braun, R. (2000). "Extraction and purification of lactic acid from silages." Bioresource Technology, 75(3), 181-187. DOI: 10.1016/S0960-8524(00)00068-7

Edwards, R. H., Miller, R. E., De Fremery, D., Knuckles, B. E., Bickoff, E. M., and Kohler, G. O. (1975). "Pilot plant production of an edible white fraction leaf protein concentrate from alfalfa." Journal of Agricultural and Food Chemistry, 23(4), 620-626. DOI: 10.1021/jf60200a046

Grass, S., and Hansen, G. (1999). "Production of ethanol and biogas, protein concentrate and technical fibers from grass/clover."In: Biomass Congress of the Americas, Proceedings; Oakland, USA.

Haque, M., Epplin, F. M., and Taliaferro, C. M. (2009). "Nitrogen and Harvest Frequency Effect on Yield and Cost for Four Perennial Grasses All rights reserved. No part of this periodical may be reproduced or transmitted in any form or by any means, electronic or mechanical, including photocopying, recording, or any information storage and retrieval system, without permission in writing from the publisher." Agron. J., 101(6), 1463-1469. DOI: 10.2134/agronj2009.0193

Hasan, R., Zhang, B., and Wang, L. (2013). "Microalgae for Biodiesel Production and Waste Water Treatment."In: Biomass Processing, Conversion and Biorefinery, B. Zhang, and Y. Wang, eds., Nova Science Publishers, Inc., Hauppauge NY, 277288.

Huber, G. W., and Dumesic, J. A. (2006). "An overview of aqueous-phase catalytic processes for production of hydrogen and alkanes in a biorefinery." Catalysis Today, 111(1-2), 119-132. DOI: 10.1016/j.cattod.2005.10.010

Kamm, B., and Kamm, M. (2007). "International biorefinery systems." Pure Appl.Chem., 79(11), 1983-1997.

Kamm, B., Schönicke, P., and Kamm, M. (2009). "Biorefining of green biomass technical an energetic considerations." CLEAN - Soil, Air, Water, 37, 27-30.

Kamm, B., Hille, C., Schönicke, P., and Dautzenberg, G. (2010). "Green biorefinery demonstration plant in Havelland (Germany)." Biofuels, Bioproducts and Biorefining, 4(3), 253-262. DOI: 10.1002/bbb.218 
Kammes, K. L., Bals, B. D., Dale, B. E., and Allen, M. S. (2011). "Grass leaf protein, a coproduct of cellulosic ethanol production, as a source of protein for livestock." Animal Feed Science and Technology, 164(1-2), 79-88. DOI: 10.1016/j.anifeedsci.2010.12.006

Kromus, S., Wachter, B., Koschuh, W., Mand1, M., Krotscheck, C., and Narodoslawsky, M. (2004). " The green biorefinery Austria - development of an integrated system for green biomass utilization." Chemical and Biochemical Engineering Quarterly, $18,7-12$.

Lardon, L., Hélias, A., Sialve, B., Steyer, J.-P., and Bernard, O. (2009). "Life-Cycle Assessment of Biodiesel Production from Microalgae." Environmental Science \& Technology, 43(17), 6475-6481. DOI: 10.1021/es900705j

Leiß, S., Venus, J., and Kamm, B. (2010). "Fermentative Production of L-Lysine-Llactate with Fractionated Press Juices from the Green Biorefinery." Chemical Engineering \& Technology, 33(12), 2102-2105.

Mandl, M. G. (2010). "Status of green biorefining in Europe." Biofuels, Bioproducts and Biorefining, 4(3), 268-274. DOI: 10.1002/bbb.219

Perlack, R. D., Wright, L. L., Turhollow, A. F., Graham, R. L., Stokes, B. J., and Erbach, D. C. (2005). "Biomass as feedstock for a bioenergy and bioproducts industry: The technical feasibility of a billion-ton annual supply." http://wwwl.eere.energy.gov/bioenergy/pdfs/final billionton vision report2.pdf. [Accessed on February 20, 2015]

Pirie, N. W. (1971). Leaf protein: its agronomy, preparation, quality and use, International Biological Programme.

Pirie, N. W. (1986). "Leaf protein after forty years." BioEssays, 5(4), 174-175. DOI: 10.1002/bies.950050409

Prochnow, A., Heiermann, M., Drenckhan, A., and Schelle, H. (2005). "Seasonal Pattern of Biomethanisation of Grass from Landscape Management." Agricultural Engineering International: CIGR Journal, 7, Manuscript EE 05011.

Richter, F., Graß, R., Fricke, T., Zerr, W., and Wachendorf, M. (2009). "Utilization of semi-natural grassland through integrated generation of solid fuel and biogas from biomass. II. Effects of hydrothermal conditioning and mechanical dehydration on anaerobic digestion of press fluids." Grass and Forage Science, 64(4), 354-363. DOI: $10.1111 / \mathrm{j} .1365-2494.2009 .00700 . \mathrm{x}$

Schmer, M. R., Vogel, K. P., Mitchell, R. B., and Perrin, R. K. (2008). "Net energy of cellulosic ethanol from switchgrass." Proceedings of the National Academy of Sciences, 105(2), 464-469. DOI: 10.1073/pnas.0704767105

Shafiee, S., and Topal, E. (2009). "When will fossil fuel reserves be diminished?" Energy Policy, 37(1), 181-189. DOI: 10.1016/j.enpol.2008.08.016

Sinclair, S. (2009). "Protein extraction from pasture. Literature review Part A: The plant fractionation bio-porcess and adaptability to farming systems." http://maxa.maf.govt.nz/sff/about-projects/search/C08-001/literature-review.pdf. [Accessed on February 20, 2015]

Singh, N. (1996). Green Vegetation Fractionation Technology, Science Publishers, Inc., Lebanon, NH, USA.

Takara, D., and Khanal, S. K. (2011). "Green processing of tropical banagrass into biofuel and biobased products: An innovative biorefinery approach." Bioresource Technology, 102(2), 1587-1592. DOI: 10.1016/j.biortech.2010.08.106 
Thang, V. H., and Novalin, S. (2008). "Green Biorefinery: Separation of lactic acid from grass silage juice by chromatography using neutral polymeric resin." Bioresource Technology, 99(10), 4368-4379. DOI: 10.1016/j.biortech.2007.08.045

Thomsen, M. (2005). "Complex media from processing of agricultural crops for microbial fermentation." Applied Microbiology and Biotechnology, 68(5), 598606. DOI: 10.1007/s00253-005-0056-0

US Department of Energy "Biomass Feedstock Composition and Property Database." http://www.afdc.energy.gov/biomass/progs/search1.cgi. [Accessed on February 20, 2015]

US EPA (2007). "Biofuels in the U.S. Transportation Sector." http://www.eia.gov/oiaf/analysispaper/biomass.html. [Accessed on February 20, 2015]

US EPA (2009). "U.S. Crude Oil, Natural Gas, and Natural Gas Liquids Reserves 2007 Annual Report." http://www.eia.gov/naturalgas/crudeoilreserves/archive/2007/full.pdf. [Accessed on February 20, 2015]

Vardon, D. R., Sharma, B. K., Blazina, G. V., Rajagopalan, K., and Strathmann, T. J. (2012). "Thermochemical conversion of raw and defatted algal biomass via hydrothermal liquefaction and slow pyrolysis." Bioresource Technology, 109(0), 178-187. DOI: 10.1016/j.biortech.2012.01.008

Wachendorf, M., Richter, F., Fricke, T., Graß, R., and Neff, R. (2009). "Utilization of semi-natural grassland through integrated generation of solid fuel and biogas from biomass. I. Effects of hydrothermal conditioning and mechanical dehydration on mass flows of organic and mineral plant compounds, and nutrient balances." Grass and Forage Science, 64(2), 132-143. DOI: 10.1111/j.13652494.2009.00677.x

Walker, H. G., Kohler, G. O., and Garrett, W. N. (1982). "Comparative Feeding Value of Alfalfa Press Cake Residues after Mechanical Extraction of Protein." J. Anim. Sci., 55(3), 498-504. DOI: 10.2134/jas1982.553498x

Woodward, W. T. W. (2008). "The Potential of Alfalfa, Switchgrass and Miscanthus As Biofuel Crops in Washington."In: Proceedings Washington State Hay Grower Association Annual Conference and Trade Show, Three Rivers Convention Center, Kennewick.

Xiu, S., and Shahbazi, A. (2013). "Green Biorefining of Green Biomass."In: Biomass Processing, Conversion and Biorefinery, B. Zhang, and Y. Wang, eds., Nova Science Publishers, Inc., Hauppauge, NY, 435-446.

Xiu, S. N., Shahbazi, A., Croonenberghs, J., and Wang, L. J. (2010). "Oil Production from Duckweed by Thermochemical Liquefaction." Energy Sources, Part A: Recovery, Utilization, and Environmental Effects, 32(14), 1293-1300. DOI: 10.1080/15567030903060408

Article copyright: (C) 2015 Shuangning Xiu and Abolghasem Shahbazi. This is an open access article distributed under the terms of the Creative Commons Attribution 4.0 International License, which permits unrestricted use and distribution provided the original author and source are credited. 